Si mple one step syntheses of i ndol e- 3 acet onitril es from i ndol e 3 car boxal dehydes

\begin{tabular}{|l|l|}
\hline 著者 & Yanada Fumi o, Hashi zume Tonoko, Somei Nasanor i \\
\hline $\begin{array}{l}\text { j our nal or } \\
\text { publ i cat i on t i t l e }\end{array}$ & Het er ocycl es \\
\hline vol une & 47 \\
\hline nunber & 1 \\
\hline page $\mathrm{r}$ ange & $509-516$ \\
\hline year & 1998-01-01 \\
\hline URL & ht t p: //hdl . handl e. net /2297/4347 \\
\hline
\end{tabular}




\title{
SIMPLE ONE STEP SYNTHESES OF INDOLE-3-ACETONITRILES FROM INDOLE-3-CARBOXALDEHYDES 1
}

\author{
Fumio Yamada, Tomoko Hashizume, and Masanori Somei* \\ Faculty of Pharmaceutical Sciences, Kanazawa University, \\ 13-1 Takara-machi, Kanazawa 920, Japan
}

\begin{abstract}
One step conversion method of indole-3-carboxaldehydes into indole-3-acetonitriles is developed. Applying the method, 4-nitro- (7a), 4-phenyl(7 b), 4-iodo- (7 c), 4-methoxy- (7 d), and 4-benzyloxyindole-3-acetonitrile (7 e) are available in two steps from indole-3-carboxaldehyde (4).
\end{abstract}

Indole-3-acetonitriles (3) are known not only as plant growth regulators ${ }^{2}$ but also as important building blocks for tryptamines and natural products. $3 \sim 5$ Probably the most common synthesis approach to them is the nucleophilic substitution with cyanide 6 for the dimethylamino group of gramines (2) which are readily obtained by Mannich reaction of indoles (1), as shown in Scheme 1.

\section{Scheme 1}

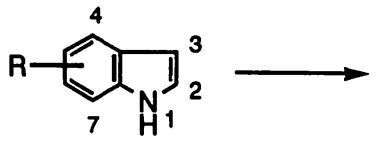

1

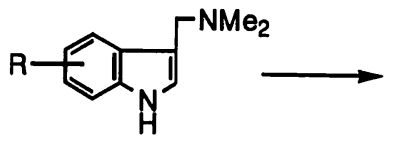

2<smiles>N#CCc1c[nH]c2ccc(Br)cc12</smiles>

3

$\mathrm{R}=$ An appropriate substituent

On the other hand, even at present, 4-substituted indole-3-acetonitriles (7, Scheme 2) are difficult to obtain due to the lack of simple preparation method for 4-substituted gramines (6). Our contribution in the indole chemistry has realized one pot syntheses 7 of 4-substituted indole-3-carboxaldehydes (5) from indole-3carboxaldehyde (4) and a direct conversion of 5 into 6.8 However, the need of one step method for transforming 5 into 7 is still remained, because the method would easily supply valuable building blocks (7a-e) and consequently provide a short cut for various natural products syntheses such as batzelline $\mathrm{C}$ (11) ${ }^{3}$ isobatzelline C (12), ${ }^{3}$ SF $2140,{ }^{4}$ nephilatoxins (13), ${ }^{5}$ and so on. Now, we wish to report the discovery of the desired reaction.

In order to accumulate basic knowledge, we chose 4-nitroindole-3-carboxaldehyde ${ }^{9}(\mathbf{5 a})$ as a substrate and tested various trials employing cyanating reagents in the presence of reducing agents, such as $\mathrm{Me}_{3} \mathrm{SiCl}$ - 
$\mathrm{NaI}-\mathrm{KCN}-\mathrm{Et}_{3} \mathrm{SiH}, \mathrm{Me}_{3} \mathrm{SiCl}-\mathrm{NaI}-\mathrm{KCN}_{\mathrm{NaBH}}, \mathrm{Me}_{3} \mathrm{SiCN}_{4} \mathrm{NaBH}_{4}$, and so on. During these studies, 8 we observed that simple treatment of 5 a sequentially with $\mathrm{NaBH}_{4}$, and then with $\mathrm{NaCN}$ in $\mathrm{MeOH}$, produced 4-nitroindole-3-acetonitrile ${ }^{9}$ (7a) and 4-nitroindole 9,10 (8). Based on the finding, further examinations of the reaction conditions were carried out, and the combination of about $1.3 \mathrm{~mol}$ eq. of $\mathrm{NaBH}_{4}$ and about $10 \mathrm{~mol}$ eq. of $\mathrm{NaCN}$ was found to be suitable for our purposes as shown in Table 1 (Entry 1), affording 7a and 8 in 36 and 53\% yields, respectively. Furthermore, when the solvent was changed to $\mathrm{MeOH}-\mathrm{MeNHCHO}(1: 1, \mathrm{v} / \mathrm{v})$, the yield of 7a increased slightly (Entry 2). Change in solvent to MeOH-DMF (1:1, v/v) increased the yield of 7a to $62 \%$ (Entry 3). It is interesting to note that $\mathrm{NH}_{2} \mathrm{CHO}$ dramatically suppressed the formation of 8 and the yield of 7a was improved (Entry 4) in comparison with the results of Entries 1 and 2. Therefore, various mixed solvents using $\mathrm{MeOH}$ and $\mathrm{NH}_{2} \mathrm{CHO}$ were examined and finally 1:1 mixture of $\mathrm{MeOH}-\mathrm{NH}_{2} \mathrm{CHO}$ was found to be a solvent of choice, producing 7a in $88 \%$ yield together with $N$-(4-nitroindol-3-yl)methylformamide (9a) as a by-product in $9 \%$ yield (Entry 5). When the same reaction was carried out without $\mathrm{NaCN}, 9 \mathrm{a}$ was exclusively produced in $75 \%$ yield together with $4 \%$ yield of 8 . Under similar reaction conditions, 9 b-f were prepared in $68,72,57,62$, and $64 \%$ yields, respectively.

\section{Scheme 2}

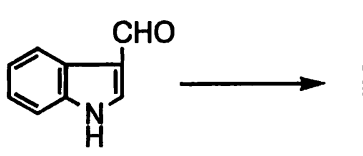<smiles>[R]c1cccc2[nH]cc(C=O)c12</smiles>

5

4
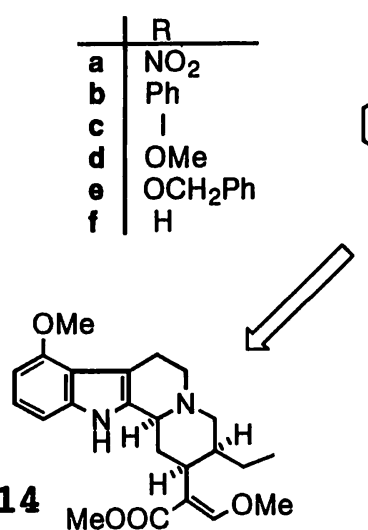

7

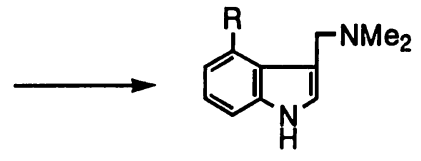

6
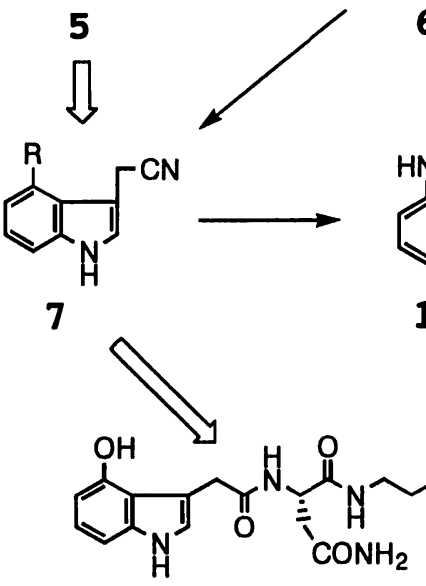

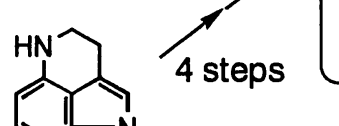

10

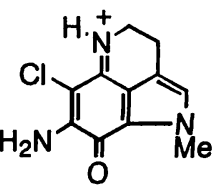<smiles></smiles>

11

12

Employing the above reaction conditions, various indole-3-acetonitriles (7b-f) having phenyl, halogen, oxygen functional groups, were obtained in excellent to good yields as shown in Table 2 in one step from the corresponding indole-3-carboxaldehydes (5b-f) together with a small amount of $9 \mathbf{b}-\mathbf{f}$, respectively. Thus, we succeeded in developing a simple one step conversion method of indole-3-carboxaldehydes into 
Table 1<smiles>O=Cc1c[nH]c2cccc([N+](=O)[O-])c12</smiles>

$5 a$<smiles>N#CCc1c[nH]c2cccc([N+](=O)[O-])c12</smiles>

$7 a$<smiles>O=CNCc1c[nH]c2cccc([N+](=O)[O-])c12</smiles>

8

9 a

\begin{tabular}{|c|c|c|c|c|}
\hline \multirow{2}{*}{ Entry } & \multirow{2}{*}{ Solvent } & \multicolumn{2}{|c|}{ Yield (\%) } & \multirow[b]{2}{*}{$9 \mathbf{a}$} \\
\hline & & $7 \mathbf{a}$ & 8 & \\
\hline 1 & $\mathrm{MeOH}$ & 36 & 53 & 0 \\
\hline 2 & $\mathrm{MeOH}-\mathrm{MeNHCHO}(1: 1, v / v)$ & 52 & 27 & 0 \\
\hline 3 & $\mathrm{MeOH}-\mathrm{DMF}(1: 1, \mathrm{v} / \mathrm{v})$ & 62 & 31 & 0 \\
\hline 4 & $\mathrm{NH}_{2} \mathrm{CHO}$ & 61 & 6 & 3 \\
\hline 5 & $\mathrm{MeOH}-\mathrm{NH}_{2} \mathrm{CHO}(1: 1, \mathrm{v} / \mathrm{v})$ & 88 & 2 & 9 \\
\hline 6 & $\mathrm{MeOH}-\mathrm{NH}_{2} \mathrm{CHO}(1: 7, \mathrm{v} / \mathrm{v})$ & 69 & 9 & 5 \\
\hline
\end{tabular}

\section{Table 2}

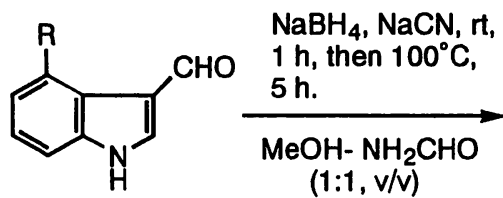

5<smiles>[R]c1cccc2[nH]cc(C[N+]#N)c12</smiles>

7<smiles>[R]c1cccc2[nH]cc(CNC=O)c12</smiles>

9

\begin{tabular}{lllll}
\hline & $\mathrm{R}$ & $\mathbf{7}$ & $\mathbf{9}$ & $\mathbf{8}$ \\
\hline a & $\mathrm{NO}_{2}$ & 88 & 9 & 2 \\
b & $\mathrm{Ph}$ & 89 & 5 & 0 \\
c & 1 & 88 & 7 & 0 \\
d & $\mathrm{OMe}_{\text {o }}$ & 86 & 11 & 0 \\
f & $\mathrm{OCH}_{2} \mathrm{Ph}$ & 89 & 9 & 0 \\
\hline
\end{tabular}


indole-3-acetonitriles. Owing to the present method, 1,3,4,5-tetrahydropyrrolo[4,3,2-de]quinoline 3,8 (10) is obtained from 4 in three steps and our previous eight steps synthesis of marine alkaloids, batzelline $C^{3}$ (11) and isobatzelline C (1 2), ${ }^{3}$ become shorter by one step (Scheme 2). The present two steps synthesis of 4-benzyloxyindole-3-acetonitrile (7e) from 4 could substitute for an expensive four steps synthesis 5 of $7 \mathrm{e}$ from 4-hydroxyindole and would be utilized for the synthetic studies of nephillatoxins such as 13.5 4-Methoxyindole-3-acetonitrile (7 d), the aglycon of SF 2140,4 is now available in only two steps from 4 and could be applied for the syntheses of Mitragyna alkaloids such as 14.11

The present method is widely applicable for effective syntheses of indole natural products.

\section{EXPERIMENTAL}

Melting points were determined on a Yanagimoto micro melting point apparatus and are uncorrected. Infrared (IR) spectra were determined with a Shimadzu IR-420 spectrophotometer, and proton nuclear magnetic resonance $\left({ }^{1} \mathrm{H}-\mathrm{NMR}\right)$ spectra with a JEOL GSX-500 spectrometer with tetramethylsilane as an internal standard. Mass spectra (MS) were recorded on a JEOL SX-102A spectrometer. Preparative thinlayer chromatography was performed on Merck Kiesel-gel $\mathrm{GF}_{25}$ (Type 60)( $\mathrm{SiO}_{2}$ ). Column chromatography was performed on silica gel ( $\mathrm{SiO}_{2}, 100-200$ mesh, from Kanto Chemical Co. Inc.).

General procedure .......- $\mathrm{NaBH}_{4}$ (1.3 mol eq.) was added to a solution of indole-3-carboxaldehyde in $\mathrm{MeOH}$ and $\mathrm{NH}_{2} \mathrm{CHO}$. After stirring at it for $1 \mathrm{~h}, \mathrm{NaCN}$ (10 mol eq.) was added to the reaction mixture and the whole was refluxed on oil bath at $100^{\circ} \mathrm{C}$ for $5 \mathrm{~h}$ with stirring. After cooling, brine was added and the whole was extracted with $\mathrm{MeOH}-\mathrm{CHCl}_{3}(5: 95, \mathrm{v} / \mathrm{v})$. The organic layer was washed with brine, dried over $\mathrm{Na}_{2} \mathrm{SO}_{4}$, and evaporated under reduced pressure to leave the residue, which was column chromatographed on $\mathrm{SiO}_{2}$ with an appropriate solvent as an eluent.

4-Nitroindole-3-acetonitrile (7a), 4-nitroindole (8), a n d $\boldsymbol{N}$-(4-nitroindol-3-yl)methylformamide (9a) from 4-nitroindole-3-carboxaldehyde (5a): Table 1, Entry 5 -...-...- In the general procedure, $23.4 \mathrm{mg}(0.619 \mathrm{mmol})$ of $\mathrm{NaBH}_{4}, 86.0 \mathrm{mg}(0.453 \mathrm{mmol})$ of $5 \mathrm{a}, 7 \mathrm{~g} 4 \mathrm{~mL}$ of $\mathrm{MeOH}$ and $4 \mathrm{~mL}$ of $\mathrm{N} \mathrm{H}_{2} \mathrm{CHO}, 230.5 \mathrm{mg}(4.70 \mathrm{mmol})$ of $\mathrm{NaCN}$ were used. The residue was column chromatographed on $\mathrm{SiO}_{2}$ with $\mathrm{CHCl}_{3}$ and then $\mathrm{MeOH}-\mathrm{CHCl}_{3}(5: 95, \mathrm{v} / \mathrm{v})$ as an eluent to give $8(1.8 \mathrm{mg}$, $2 \%)$ as the early part of the fractions. From the middle part, $7 \mathrm{a}(80.0 \mathrm{mg}, 88 \%)$ was obtained. From the later part, $9 \mathrm{a}(8.5 \mathrm{mg}, 9 \%)$ was obtained. $7 \mathbf{a}$ and 8 are identical with the authentic samples prepared according to our procedures. $9,109 \mathrm{a}: \mathrm{mp} 224.0-225.0^{\circ} \mathrm{C}$ (yellow needles, recrystallized from $\mathrm{MeOH}$ ). IR (KBr): 3330, 3270, 1623, 1509, $1317 \mathrm{~cm}^{-1}$. 1 ${ }^{1} \mathrm{H}-\mathrm{NMR}$ (DMSO-d $6,27^{\circ} \mathrm{C}$, rotational isomers existed) $\delta$ : $4.53(16 / 9 \mathrm{H}, \mathrm{d}, J=5.4 \mathrm{~Hz}), 4.57(2 / 9 \mathrm{H}, \mathrm{d}, J=6.1 \mathrm{~Hz}), 7.28(1 \mathrm{H}, \mathrm{t}, J=8.1 \mathrm{~Hz}), 7.61(1 / 9 \mathrm{H}, \mathrm{d}, J=2.2$ $\mathrm{Hz}), 7.63(8 / 9 \mathrm{H}, \mathrm{d}, J=2.2 \mathrm{~Hz}), 7.83(8 / 9 \mathrm{H}, \mathrm{dd}, J=8.1$ and $1.0 \mathrm{~Hz}), 7.84(1 / 9 \mathrm{H}, \mathrm{dd}, J=8.1$ and 1.0 $\mathrm{Hz}), 7.86(1 / 9 \mathrm{H}$, dd, $J=8.1$ and $1.0 \mathrm{~Hz}), 7.88(8 / 9 \mathrm{H}, \mathrm{dd}, J=8.1$ and $1.0 \mathrm{~Hz}), 8.00(8 / 9 \mathrm{H}, \mathrm{dt}, J=2.0$ and $1.0 \mathrm{~Hz}), 8.06(1 / 9 \mathrm{H}, \mathrm{d}, J=11.7 \mathrm{~Hz}), 8.16\left(1 \mathrm{H}\right.$, br s, disappeared on addition of $\left.\mathrm{D}_{2} \mathrm{O}\right), 11.88(1 \mathrm{H}$, 
br s, disappeared on addition of $\left.\mathrm{D}_{2} \mathrm{O}\right)$. $\mathrm{MS} m / z: 219\left(\mathrm{M}^{+}\right)$. Anal. Calcd for $\mathrm{C}_{10} \mathrm{H}_{9} \mathrm{~N}_{3} \mathrm{O}_{3}: \mathrm{C}, 54.79 ; \mathrm{H}$, 4.14; N, 19.17. Found: C, 54.70; H, 4.15; N, 19.08 .

4-Phenylindole-3-acetonitrile (7b) and $N$-(4-phenylindol-3-yl)methylformamide (9b) from 4-phenylindole-3-carboxaldehyde (5b) ---------- In the general procedure, $22.6 \mathrm{mg}(0.597$ mmol) of $\mathrm{NaBH}_{4}, 102.8 \mathrm{mg}(0.465 \mathrm{mmol})$ of $5 \mathrm{~b}, 7 \mathrm{~b}, \mathrm{~d} 4 \mathrm{~mL}$ of $\mathrm{MeOH}$ and $4 \mathrm{~mL}$ of $\mathrm{NH}_{2} \mathrm{CHO}, 230.8 \mathrm{mg}$ (4.71 mmol) of $\mathrm{NaCN}$ were used. The residue was column chromatographed on $\mathrm{SiO}_{2}$ with $\mathrm{CHCl}_{3}$ and then $\mathrm{MeOH}-\mathrm{CHCl}_{3}(5: 95, \mathrm{v} / \mathrm{v})$ as an eluent to give $7 \mathbf{b}(96.1 \mathrm{mg}, 89 \%)$ as the early part of the fractions. From the later part, $9 \mathrm{~b}(5.6 \mathrm{mg}, 5 \%)$ was obtained. $7 \mathrm{~b}$ : colorless oil. IR (film): 3380, 3320, 2250, 1611, 1484, 1411, $1335 \mathrm{~cm}^{-1}$. 1 $\mathrm{H}-\mathrm{NMR}\left(\mathrm{CDCl}_{3}\right)$ 8: $3.25(2 \mathrm{H}, \mathrm{d}, J=1.2 \mathrm{~Hz}), 7.03(1 \mathrm{H}, \mathrm{dd}, J=7.2$ and 1.0 $\mathrm{Hz}), 7.27(1 \mathrm{H}$, dd, $J=8.1$ and $7.2 \mathrm{~Hz}), 7.31(1 \mathrm{H}, \mathrm{dt}, J=2.4$ and $1.2 \mathrm{~Hz}), 7.39-7.48(6 \mathrm{H}, \mathrm{m}), 8.32(1 \mathrm{H}$, br s). High resolution MS m/z: Calcd for $\mathrm{C}_{16} \mathrm{H}_{12} \mathrm{~N}_{2}$ : 232.1001. Found: 232.1000. 9 b: mp 197.0$198.0^{\circ} \mathrm{C}$ (colorless leaves, recrystallized from $\mathrm{MeOH}$ ). IR (KBr): $3270,3150,1631,1532,1355 \mathrm{~cm}^{-1}$. $1_{\mathrm{H}-N M R}$ (DMSO-d $6,27^{\circ} \mathrm{C}$, rotational isomers existed) $\delta: 3.86(14 / 8 \mathrm{H}, \mathrm{d}, J=5.4 \mathrm{~Hz}), 3.94(2 / 8 \mathrm{H}, \mathrm{d}$, $J=6.1 \mathrm{~Hz}), 6.82(7 / 8 \mathrm{H}$, dd, $J=7.1$ and $1.0 \mathrm{~Hz}), 6.84(1 / 8 \mathrm{H}, \mathrm{dd}, J=7.1$ and $1.0 \mathrm{~Hz}), 7.13(7 / 8 \mathrm{H}$, dd, $J=8.1$ and $7.1 \mathrm{~Hz}), 7.14(1 / 8 \mathrm{H}, \mathrm{dd}, J=8.1$ and $7.1 \mathrm{~Hz}), 7.23(7 / 8 \mathrm{H}, \mathrm{dt}, J=2.4$ and $1.2 \mathrm{~Hz}), 7.25$ $(1 / 8 \mathrm{H}, \mathrm{s}), 7.34-7.48(50 / 8 \mathrm{H}, \mathrm{m}), 7.86(7 / 8 \mathrm{H}, \mathrm{s}), 7.87\left(7 / 8 \mathrm{H}\right.$, br s, disappeared on addition of $\left.\mathrm{D}_{2} \mathrm{O}\right)$, $11.16\left(7 / 8 \mathrm{H}\right.$, br s, disappeared on addition of $\left.\mathrm{D}_{2} \mathrm{O}\right), 11.19\left(1 / 8 \mathrm{H}\right.$, br s, disappeared on addition of $\left.\mathrm{D}_{2} \mathrm{O}\right)$. MS m/z: $250\left(\mathrm{M}^{+}\right)$. Anal. Calcd for $\mathrm{C}_{16} \mathrm{H}_{14} \mathrm{~N}_{2} \mathrm{O}: \mathrm{C}, 76.78 ; \mathrm{H}, 5.64 ; \mathrm{N}, 11.19$. Found: C, 76.62; H, $5.60 ; \mathrm{N}, 11.15$.

4-Iodoindole-3-acetonitrile (7c) and $N$-(4-iodoindol-3-yl)methylformamide (9c) from 4 iodoindole-3-carboxaldehyde (5c) --..-.-.-- In the general procedure, $21.0 \mathrm{mg}(0.555 \mathrm{mmol})$ of $\mathrm{NaBH}_{4}, 121.0 \mathrm{mg}(0.447 \mathrm{mmol})$ of $5 \mathrm{c}, 7 \mathrm{a}, \mathrm{c} 4 \mathrm{~mL}$ of $\mathrm{MeOH}$ and $4 \mathrm{~mL}$ of $\mathrm{NH}_{2} \mathrm{CHO}, 226.0 \mathrm{mg}(4.61$ mmol) of $\mathrm{NaCN}$ were used. The residue was column chromatographed on $\mathrm{SiO}_{2}$ with $\mathrm{MeOH}-\mathrm{CHCl}_{3}$ (1:99, $\mathrm{v} / \mathrm{v})$ and then $\mathrm{MeOH}-\mathrm{CHCl}_{3}(5: 95, \mathrm{v} / \mathrm{v})$ as an eluent to give $7 \mathrm{c}(111.3 \mathrm{mg}, 88 \%)$ as the early part of the fractions. From the later part, $9 \mathrm{c}(9.9 \mathrm{mg}, 7 \%)$ was obtained. $7 \mathrm{c}$ is identical with the authentic samples prepared according to our procedures. 9 $9 \mathrm{c}$ : $\mathrm{mp}$ 207.0-209.0 ${ }^{\circ} \mathrm{C}$ (colorless needles, recrystallized from $\mathrm{MeOH}$ ). IR (KBr): 3270, 3120, 1628, 1532, $1353 \mathrm{~cm}^{-1}$. ${ }^{1} \mathrm{H}-\mathrm{NMR}$ (DMSO-d $6,27^{\circ} \mathrm{C}$, rotational isomers existed) $\delta: 4.65(20 / 11 \mathrm{H}, \mathrm{d}, J=5.4 \mathrm{~Hz}), 4.74(2 / 11 \mathrm{H}, \mathrm{d}, J=5.9 \mathrm{~Hz}), 6.83(1 \mathrm{H}, \mathrm{dd}, J=8.1$ and $7.6 \mathrm{~Hz})$, $7.32(1 / 11 \mathrm{H}, \mathrm{d}, J=2.2 \mathrm{~Hz}), 7.37(10 / 11 \mathrm{H}, \mathrm{d}, J=2.7 \mathrm{~Hz}), 7.42(1 \mathrm{H}, \mathrm{dd}, J=8.1$ and $1.0 \mathrm{~Hz}), 7.46$ $(1 / 11 \mathrm{H}, \mathrm{dd}, J=7.6$ and $1.0 \mathrm{~Hz}), 7.47(10 / 11 \mathrm{H}, \mathrm{dd}, J=7.6$ and $1.0 \mathrm{~Hz}), 7.86(1 / 11 \mathrm{H}$, br s,. disappeared on addition of $\left.\mathrm{D}_{2} \mathrm{O}\right), 8.07(10 / 11 \mathrm{H}, \mathrm{dt}, J=2.0$ and $1.0 \mathrm{~Hz}), 8.17(1 / 11 \mathrm{H}, \mathrm{d}, J=11.7 \mathrm{~Hz}), 8.21(10 / 11 \mathrm{H}$, br s, disappeared on addition of $\left.\mathrm{D}_{2} \mathrm{O}\right), 11.28\left(1 \mathrm{H}\right.$, br $\mathrm{s}$, disappeared on addition of $\left.\mathrm{D}_{2} \mathrm{O}\right)$. MS $m / z: 300$ $\left(\mathrm{M}^{+}\right)$. Anal. Calcd for $\mathrm{C}_{10} \mathrm{H}_{9} \mathrm{IN}_{2} \mathrm{O}$ : C, 40.02; H, 3.02; N, 9.33. Found: C, 40.06; H, 2.99; N, 9.09.

4-Methoxyindole-3-acetonitrile (7d) and $\boldsymbol{N}$-(4-methoxyindol-3-yl)methylformamide (9d) from 4-methoxyindole-3-carboxaldehyde (5d) In the general procedure, $23.0 \mathrm{mg}$ 
$(0.608 \mathrm{mmol})$ of $\mathrm{NaBH}_{4}, 80.4 \mathrm{mg}(0.459 \mathrm{mmol})$ of $5 \mathrm{~d}, 7 \mathrm{a} 4 \mathrm{~mL}$ of $\mathrm{MeOH}$ and $4 \mathrm{~mL}$ of $\mathrm{NH}_{2} \mathrm{CHO}, 223.8$ $\mathrm{mg}$ (4.57 mmol) of $\mathrm{NaCN}$ were used. The residue was column chromatographed on $\mathrm{SiO}_{2}$ with $\mathrm{CHCl}_{3}$ as an eluent to give $7 \mathrm{~d}(73.5 \mathrm{mg}, 86 \%)$ as the early part of the fractions. From the later part, $9 \mathrm{~d}(10.2 \mathrm{mg}$, $11 \%$ ) was obtained. $7 \mathrm{~d}$ : $\mathrm{mp} 145.0-146.0^{\circ} \mathrm{C}$ (colorless prisms, recrystallized from $\mathrm{CHCl}_{3}$-hexane). I R (KBr): 3360, 2270, 1617, 1590, 1509, 1355, 1260, 1091, 752, $733 \mathrm{~cm}^{-1}$. 1 ${ }_{\mathrm{H}-\mathrm{NMR}}\left(\mathrm{CDCl}_{3}\right)$ 8: 3.92 $(3 \mathrm{H}, \mathrm{s}), 4.05(2 \mathrm{H}, \mathrm{d}, J=1.1 \mathrm{~Hz}), 6.50(1 \mathrm{H}, \mathrm{d}, J=8.0 \mathrm{~Hz}), 6.96(1 \mathrm{H}, \mathrm{d}, J=8.0 \mathrm{~Hz}), 7.09(1 \mathrm{H}, \mathrm{dt}$, $J=2.2$ and $1.1 \mathrm{~Hz}), 7.12(1 \mathrm{H}, \mathrm{t}, J=8.0 \mathrm{~Hz}), 8.08\left(1 \mathrm{H}\right.$, br s, disappeared on addition of $\left.\mathrm{D}_{2} \mathrm{O}\right)$. MS $m / z$ : $186\left(\mathrm{M}^{+}\right)$. Anal. Calcd for $\mathrm{C}_{11} \mathrm{H}_{10} \mathrm{~N}_{2} \mathrm{O}: \mathrm{C}, 70.95 ; \mathrm{H}, 5.41 ; \mathrm{N}, 15.04$. Found: C, 70.98; H, 5.41; N, 15.11. $9 \mathrm{~d}: \mathrm{mp}$ 190.0-192.0 $0^{\circ} \mathrm{C}$ (colorless prisms, recrystallized from $\mathrm{MeOH}$ ). IR (KBr): 3230,3180 , $1635,1354 \mathrm{~cm}^{-1} .1^{1} \mathrm{H}-\mathrm{NMR}$ (DMSO-d $6,27^{\circ} \mathrm{C}$, rotational isomers existed) $\delta: 3.84(3 \mathrm{H}, \mathrm{s}), 4.49(2 / 6 \mathrm{H}, \mathrm{d}$, $J=6.1 \mathrm{~Hz}), 4.51(10 / 6 \mathrm{H}, \mathrm{d}, J=5.6 \mathrm{~Hz}), 6.46(1 \mathrm{H}, \mathrm{dd}, J=7.6$ and $0.7 \mathrm{~Hz}), 6.93(5 / 6 \mathrm{H}, \mathrm{dd}, J=8.1$ and $1.0 \mathrm{~Hz}), 6.94(1 / 6 \mathrm{H}, \mathrm{dd}, J=8.1$ and $1.0 \mathrm{~Hz}), 6.98(5 / 6 \mathrm{H}, \mathrm{dd}, J=8.1$ and $7.6 \mathrm{~Hz}), 6.99(1 / 6 \mathrm{H}$, dd, $J=8.1$ and $7.6 \mathrm{~Hz}), 7.06(1 \mathrm{H}, \mathrm{d}, J=2.4 \mathrm{~Hz}), 7.72\left(1 / 6 \mathrm{H}\right.$, br s, disappeared on addition of $\left.\mathrm{D}_{2} \mathrm{O}\right), 8.04$ $(5 / 6 \mathrm{H}, \mathrm{d}, J=1.7 \mathrm{~Hz}), 8.05\left(5 / 6 \mathrm{H}\right.$, br s, disappeared on addition of $\left.\mathrm{D}_{2} \mathrm{O}\right), 8.12(1 / 6 \mathrm{H}, \mathrm{d}, J=11.7 \mathrm{~Hz})$, $10.88\left(5 / 6 \mathrm{H}\right.$, br s, disappeared on addition of $\left.\mathrm{D}_{2} \mathrm{O}\right), 10.90\left(1 / 6 \mathrm{H}\right.$, br s, disappeared on addition of $\left.\mathrm{D}_{2} \mathrm{O}\right)$. MS m/z: $204\left(\mathrm{M}^{+}\right)$. Anal. Calcd for $\mathrm{C}_{11} \mathrm{H}_{12} \mathrm{~N}_{2} \mathrm{O}_{2} \cdot 1 / 8 \mathrm{H}_{2} \mathrm{O}: \mathrm{C}, 63.99 ; \mathrm{H}, 5.98 ; \mathrm{N}, 13.57$. Found: $\mathrm{C}$, 63.91; H, 5.87; N, 13.33.

\section{4-Benzyloxyindole-3-acetonitrile (7e) and $N$-(4-methoxyindol-3-yl)methylformamide}

(9e) from 4-benzyloxyindole-3-carboxaldehyde (5e) In the general procedure, 26.2 $\mathrm{mg}(0.693 \mathrm{mmol})$ of $\mathrm{NaBH}_{4}, 111.0 \mathrm{mg}(0.442 \mathrm{mmol})$ of $5 \mathrm{e}, 7 \mathrm{a} 4 \mathrm{~mL}$ of $\mathrm{MeOH}$ and $4 \mathrm{~mL}$ of $\mathrm{NH}_{2} \mathrm{CHO}$, $222.7 \mathrm{mg}$ (4.54 mmol) of $\mathrm{NaCN}$ were used. The residue was column chromatographed on $\mathrm{SiO}_{2}$ with $\mathrm{CHCl}_{3}$ and then $\mathrm{MeOH}-\mathrm{CHCl}_{3}(5: 95, \mathrm{v} / \mathrm{v})$ as an eluent to give $7 \mathrm{e}(102.8 \mathrm{mg}, 89 \%)$ as the early part of the fractions. From the later part, 9 e $(11.2 \mathrm{mg}, 9 \%)$ was obtained. $7 \mathrm{e}: \mathrm{mp} 84.0-86.0^{\circ} \mathrm{C}$ (colorless needles, recrystallized from benzene). IR (KBr): $3380,2260,1616,1590,1507,1261 \mathrm{~cm}^{-1}$. ${ }^{1} \mathrm{H}-\mathrm{NMR}\left(\mathrm{CDCl}_{3}\right) \delta$ : $4.02(2 \mathrm{H}, \mathrm{d}, J=1.2 \mathrm{~Hz}), 5.18(2 \mathrm{H}, \mathrm{s}), 6.59(1 \mathrm{H}, \mathrm{d}, J=7.8 \mathrm{~Hz}), 6.99(1 \mathrm{H}, \mathrm{d}, J=8.1 \mathrm{~Hz}), 7.11(1 \mathrm{H}, \mathrm{dd}$, $J=8.1$ and $7.8 \mathrm{~Hz}), 7.12(1 \mathrm{H}, \mathrm{dt}, J=2.4$ and $1.2 \mathrm{~Hz}), 7.35(1 \mathrm{H}$, br t, $J=7.3 \mathrm{~Hz}), 7.42(2 \mathrm{H}$, br t, $J=7.3$ $\mathrm{Hz}$ ), $7.49(2 \mathrm{H}$, br d, $J=7.3 \mathrm{~Hz}), 8.12\left(1 \mathrm{H}\right.$, br s). MS $m / z: 262\left(\mathrm{M}^{+}\right)$. Anal. Calcd for $\mathrm{C}_{17} \mathrm{H}_{14} \mathrm{~N}_{2} \mathrm{O}: \mathrm{C}$, 77.84; H, 5.38; N, 10.68. Found: C, 77.83; H, 5.39; N, 10.37. 9 e: colorless oil. IR (film): 3370, 3260, $1661,1502,1260 \mathrm{~cm}^{-1}$. $1_{\mathrm{H}-\mathrm{NMR}}$ (DMSO-d $6,27^{\circ} \mathrm{C}$, rotational isomers existed) $\delta: 4.51(2 / 7 \mathrm{H}, \mathrm{d}, J=6.1$ $\mathrm{Hz}), 4.54(12 / 7 \mathrm{H}, \mathrm{d}, J=5.4 \mathrm{~Hz}), 5.20(2 \mathrm{H}, \mathrm{s}), 6.54-6.59,(1 \mathrm{H}, \mathrm{m}), 6.94-6.99(2 \mathrm{H}, \mathrm{m}), 7.06(1 / 7 \mathrm{H}, \mathrm{d}$, $J=2.4 \mathrm{~Hz}), 7.08(6 / 7 \mathrm{H}, \mathrm{d}, J=2.4 \mathrm{~Hz}), 7.29-7.43(3 \mathrm{H}, \mathrm{m}), 7.52(2 \mathrm{H}$, br d, $J=7.6 \mathrm{~Hz}), 7.70(1 / 7 \mathrm{H}, \mathrm{br}$ s, disappeared on addition of $\left.\mathrm{D}_{2} \mathrm{O}\right), 7.96(1 / 7 \mathrm{H}, \mathrm{d}, J=11.7 \mathrm{~Hz}), 8.02(6 / 7 \mathrm{H}, \mathrm{dt}, J=2.0$ and $1.0 \mathrm{~Hz})$, $8.08\left(6 / 7 \mathrm{H}\right.$, br $\mathrm{s}$, disappeared on addition of $\left.\mathrm{D}_{2} \mathrm{O}\right), 10.93\left(1 \mathrm{H}\right.$, br $\mathrm{s}$, disappeared on addition of $\left.\mathrm{D}_{2} \mathrm{O}\right)$. High resolution MS m/z: Calcd for $\mathrm{C}_{17} \mathrm{H}_{16} \mathrm{~N}_{2} \mathrm{O}_{2}$ : 280.1212 . Found: 280.1208 .

Indole-3-acetonitrile (7f) and $\boldsymbol{N}$-(indol-3-yl)methylformamide (9f) from indole-3-car- 
boxaldehyde $(5 \mathrm{f})$----------- In the general procedure, $23.4 \mathrm{mg}(0.619 \mathrm{mmol})$ of $\mathrm{NaBH}_{4}, 68.4 \mathrm{mg}$ ( $0.472 \mathrm{mmol})$ of $5 \mathrm{f}, 4 \mathrm{~mL}$ of $\mathrm{MeOH}$ and $4 \mathrm{~mL}$ of $\mathrm{NH}_{2} \mathrm{CHO}, 237.0 \mathrm{mg}$ (4.84 mmol) of NaCN were used. The residue was column chromatographed on $\mathrm{SiO}_{2}$ with $\mathrm{CHCl}_{3}$ and then $\mathrm{MeOH}-\mathrm{CHCl}_{3}(5: 95$, v/v) as an eluent to give $7 \mathbf{f}(70.1 \mathrm{mg}, 95 \%)$ as the early part of the fractions. From the later part, $9 \mathrm{f}(3.6 \mathrm{mg}, 4 \%)$ was obtained. $7 \mathrm{f}$ was identical with the commercially available sample. 9 f: colorless oil. IR (film): 3370 , $3260,1656 \mathrm{~cm}^{-1}$. ${ }^{1} \mathrm{H}-\mathrm{NMR}$ (DMSO-d $6,27^{\circ} \mathrm{C}$, rotational isomers existed) $\delta: 4.42(2 / 10 \mathrm{H}, \mathrm{d}, J=5.9 \mathrm{~Hz})$, $4.43(18 / 10 \mathrm{H}, \mathrm{d}, J=5.9 \mathrm{~Hz}), 6.99(9 / 10 \mathrm{H}$, ddd, $J=8.1,7.1$, and $1.0 \mathrm{~Hz}), 7.00(1 / 10 \mathrm{H}$, ddd, $J=8.1$, 7.1 , and $1.0 \mathrm{~Hz}), 7.08(9 / 10 \mathrm{H}$, ddd, $J=8.1,7.1$, and $1.0 \mathrm{~Hz}), 7.09(1 / 10 \mathrm{H}$, ddd, $J=8.1,7.1$, and 1.0 $\mathrm{Hz}), 7.24(1 / 10 \mathrm{H}, \mathrm{d}, J=2.4 \mathrm{~Hz}), 7.26(9 / 10 \mathrm{H}, \mathrm{d}, J=2.4 \mathrm{~Hz}), 7.35(9 / 10 \mathrm{H}, \mathrm{dt}, J=8.1$ and $1.0 \mathrm{~Hz}), 7.36$ $(1 / 10 \mathrm{H}, \mathrm{dt}, J=8.1$ and $1.0 \mathrm{~Hz}), 7.54(9 / 10 \mathrm{H}$, br $\mathrm{d}, J=8.1 \mathrm{~Hz}), 7.56(1 / 10 \mathrm{H}, \mathrm{br} \mathrm{d}, J=8.1 \mathrm{~Hz}), 8.04$ $\left(1 / 10 \mathrm{H}\right.$, br s, disappeared on addition of $\left.\mathrm{D}_{2} \mathrm{O}\right), 8.06(9 / 10 \mathrm{H}, \mathrm{dt}, J=2.0$ and $1.0 \mathrm{~Hz}), 8.21(1 / 10 \mathrm{H}, \mathrm{d}$, $J=11.7 \mathrm{~Hz}), 8.25\left(9 / 10 \mathrm{H}\right.$, br $\mathrm{s}$, disappeared on addition of $\left.\mathrm{D}_{2} \mathrm{O}\right), 10.91(1 \mathrm{H}$, br s, disappeared on addition of $\mathrm{D}_{2} \mathrm{O}$ ). High resolution $\mathrm{MS} m / z$ : Calcd for $\mathrm{C}_{10} \mathrm{H}_{10} \mathrm{~N}_{2} \mathrm{O}$ : 174.0793. Found: 174.0793 .

N-(4-Nitroindol-3-yl)methylformamide (9a) from 4-nitroindole-3-carboxaldehyde (5a) --

- In the general procedure, $25.0 \mathrm{mg}(0.661 \mathrm{mmol})$ of $\mathrm{NaBH}_{4}, 86.0 \mathrm{mg}(0.453 \mathrm{mmol})$ of $5 \mathrm{a}, 4 \mathrm{~mL}$ of $\mathrm{MeOH}$, and $4 \mathrm{~mL}$ of $\mathrm{NH}_{2} \mathrm{CHO}$ were used. After stirring at room temperature for $1 \mathrm{~h}$, the whole was refluxed on oil bath at $100^{\circ} \mathrm{C}$ for an additional $12 \mathrm{~h}$ with stirring. The residue was recrystallized from $\mathrm{MeOH}$ to afford $9 \mathrm{a}$ as yellow needles $(50.3 \mathrm{mg})$. Mother liquor was purified by column chromatography on $\mathrm{SiO}_{2}$ with $\mathrm{CHCl}_{3}$ and then $\mathrm{MeOH}-\mathrm{CHCl}_{3}(5: 95, \mathrm{v} / \mathrm{v})$ as an eluent to give $8(3.2 \mathrm{mg}, 4 \%)$ as the early part of the fractions. From the later part, 9a $(24.2 \mathrm{mg})$ was obtained. Total yield of $9 \mathrm{a}$ was $74.5 \mathrm{mg}$ $(75 \%)$.

Similar experiments starting from 5 b-f afforded 9 b-f in $68,72,57,62$, and $64 \%$ yields, respectively.

\section{REFERENCES AND NOTES}

1. a) Dedicated to the 75th birthday of Dr. Koji Nakanishi. b) This is Part 83 of a series entitled "The Chemistry of Indoles”. Part 82: M. Somei and K. Nakagawa, Heterocycles, 1997, 45, submitted.

2. E. R. H. Jones and W. C. Taylor, Nature, 1957, 179, 1138; T. Okamoto, Y. Isogai, T. Koizumi, H. Fujishiro, and Y. Sato, Chem. Pharm. Bull., 1967, 15, 163; M. Nomoto and S. Tamura, Agr. Biol. Chem., 1970, 34, 1590; D. Edgerton, A. Tropsha, and A. M. Jones, Phytochemistry, 1994, 35 , 1111 and references cited therein.

3. F. Yamada, S. Hamabuchi, A. Shimizu, and M. Somei, Heterocycles, 1995, 41, 1905 and references cited therein.

4. T. Ito, K. Ohba, M. Koyama, M. Sezaki, H. Tohyama, T. Shomura, H. Fukuyasu, Y. Kazuno, T. Niwa, M. Kojima, and T. Niida, J. Antibiotics, 1984, 37, 931; J. G. Buchanan, J. Stoddart, and R. H. Wightman, J. Chem. Soc., Chem. Commun., 1989, 823. Synthetic work of the sugar part of 
SF2140: D. Fattori and P. Vogel, Tetrahedron, 1992, 48, 10587.

5. T. Shinada, M. Miyachi, Y. Itagaki, H. Naoki, K. Yoshihara, and T. Nakajima, Tetrahedron Lett., 1996, 37, 7099 and references cited therein.

6. R. J. Sundberg, "The Chemistry of Indoles", Academic Press, New York, 1970; R. T. Brown, J. A. Joule, and P. G. Sammes, "Comprehensive Organic Chemistry", Vol. 4, ed. by P. G. Sammes, Pergamon Press, Oxford, 1979, pp. 411-492; R. J. Sundberg, “Indoles”, Academic Press, New York, 1996.

7. a) M. Somei, F. Yamada, M. Kunimoto, and C. Kaneko, Heterocycles, 1984, 22, 797; b) M. Somei, H. Amari, and Y. Makita, Chem. Pharm. Bull., 1986, 34, 3971; c) F. Yamada and M. Somei, Heterocycles, 1987, 26, 1173; d) M. Somei, F. Yamada, and K. Naka, Chem. Pharm. Bull., 1987, 35, 1322; e) M. Somei, M. Wakida, and T. Ohta, ibid., 1988, 36, 1162; f) M. Somei, T. Ohta, J. Shinoda, and Y. Somada, Heterocycles, 1989, 29, 653; g) M. Somei, F. Yamada, H. Hamada, and T. Kawasaki, ibid., 1989, 29, 643; h) Review: M. Somei, Yakugaku Zasshi, 1988, 108, 361 and references cited therein.

8. F. Yamada, K. Kobayashi, A. Shimizu, N. Aoki, and M. Somei, Heterocycles, 1993, 36, 2783 and references cited therein.

9. M. Somei, K. Kizu, M. Kunimoto, and F. Yamada, Chem. Pharm. Bull., 1985, 33, 3696.

10. M. Somei and M. Tsuchiya, Chem. Pharm. Bull., 1981, 29, 3145. Other literatures for the preparation of 4-nitroindole are summarized in the reference of 8.

11. C. M. Lee, W. F. Trager, and A. H. Beckett, Tetrahedron, 1967, 23, 375; H. M-Manga, J. QLeclerco, G. Llabres, M-L. B-Pinheiro, A. F. I. Da Rocha, and L. Angenot, Phytochemistry, 1996, 43, 1125. 